\title{
Construction Rubble, Foundry Sand and Marble Waste Powder; as Raw Materials on Concrete Bricks Production
}

\author{
Maher. A. El- Sockary ${ }^{1}$, Amany. F.Hasballah², Omnya A. El- El-Batrawy², Abdel Fattah,.M.Gharieb ${ }^{2}$ and Maie \\ .I. El-Gammal ${ }^{2 *}$ \\ ${ }^{1}$ Egyptian Petroleum Research Institute, Nasr City, Egypt \\ ${ }^{2}$ Environmental Sciences Department, Faculty of Science, Damietta University, Egypt
}

Received: 2018 /Accepted: 13 May 2018

* Corresponding author: esraaeltwargy@du.edu.eg

\begin{abstract}
The construction wastes is one of the environmental problem not only in Egypt but also in the whole world. The main objective of this paper to evaluated the fully replacing of natural aggregate (NA) by construction wastes (CW), full replace of natural sand (NS) by foundry sand (FS) and partially replaced of Portland cement (OPC) by marble fine waste (MFW) on the compressive strength was found out at 7, 28 days and 90 days and explained if these trials could be used in bricks manufacturing so Concrete cubes of size $150 * 150 * 150 \mathrm{~mm}$ were prepared in this paper with a different replacement ratio of Portland cement (PC) by marble fine waste (MFW) were 0\%, 10\%, $20 \%, 30 \%$ and $50 \%$ by weight of cement.

Results show that the compressive strength by $0 \%, 10 \% 20 \%, 30 \%$ and $50 \%$ at 7 , and 28 days which the cement was replace ratio of marble fine waste (MFW) (140-141,92-91,90-86,82-80, and 73-76 $\mathrm{kg} / \mathrm{cm} 2)$ respectively. The compressive strength of sample $50 \%$ replacement gives compressive strength $(73-76 \mathrm{~kg} / \mathrm{cm} 2)$ which consider as lowest compressive strength of these trials however it utilized maximum amount of marble dust which contributed to the elimination of the largest amount of wastes and also can be used successfully in the concrete bricks manufacturing as Egyptian standard No. 1292 and Egyptian code ECP 204 which give the compressive strength is $70 \mathrm{~kg} / \mathrm{cm} 2$. The present study demostrated that, the mixture can used in brick manufacturing as shipper and green method to utilize the different waste and make new sustainability products.
\end{abstract}

Keywords: concrete, sustainable, bricks, compressive strength.

\section{Introduction}

A lot of solid wastes which have negative effects on the environment, human health, soil, and air; so it will need additional costs to remove or safe disposal. Therefore, the utilization of this solid in building products will be completed by a positive economic impact for environmental development.

The most common and widely used building material in the world is concrete. With the used of a large amount of concrete, pollution is becoming more and more serious. The classical materials produced from the natural resources which use in construction such as concrete, bricks, hollow blocks, solid blocks, pavement blocks, and tiles. This will pose a bad effect on the environment due to continuous exploration and diminish of natural resources quantities. Moreover, various toxic substances such as high concentration of carbon monoxide, sulfur oxides, nitrogen oxides, and suspended particulate matters are invariably 
emitted to the atmosphere during the manufacturing process of construction materials. The emission of toxic matters contaminates air, water, soil and aquatic life, and thus influences human health as well as their living standard atmosphere (Król and Blaszczyński, 2013).

Large quantities of solid wastes being generated worldwide from sources such as household, domestic, industrial, commercial and construction demolition activities, lead to environmental concerns. Solid wastes are substances and masses resulted by the various human activities that have to be dumped. These wastes are generated around the globe in both developed and developing countries due to population growth, the rise in living standard and urbanization (Safiuddin et al., 2010).

Cement replacement materials are the way to utilized untouchable raw materials and should be a break-solution of the green world. Materials that can be used for replacing cement as a binder can come from several sources. Recycling as part of environmental considerations has become a common feature in the construction industry. That waste components include Portland cement concrete, asphalt concrete, wood, drywall, asphalt shingles, metal, cardboard, plastic, and soil. This waste material has only recently gained attention as concerns about its environmental impact have developed (Tomas and Ganiron, 2015).

Emission of greenhouse effect gasses is wellknown problem that makes our environment changed permanently. $\mathrm{CO}_{2}$ is major gas causing this problem. One of the global environmental impacts of solid waste is also methane emission is regarded as a powerful greenhouse gas GHG, whose impact can be felt within a short period of time. Flooding, air pollution, and other public health impact are also associated with solid waste (Moirangthem and Meetei, 2017).

Green concrete should follow reduce, reuse and recycle technique or any two processes in the concrete technology. The three major objective behind green concept in concrete is to reduce greenhouse gas emission (carbon dioxide emission from cement industry); to reduce the use of natural resources such as limestone, shale, clay, natural river sand, natural rocks that are being consume for the development of human mankind that are not given back to the earth; and the use of waste materials in concrete that results in the air, land and water pollution. This objective behind green concrete will result in the sustainable development without destruction natural resources. This means that the concrete uses less energy in its production and produces less carbon dioxide than normal concrete. Green concrete is very often and also cheap to produce because, waste products are used as a partial substitute for cement, charges for the disposal of waste are avoided, energy consumption in production is lower, and durability is greater (Suhendro,2014). In other words, it can define as an environmentally friendly concrete "eco-friendly". Green concrete improves the three sides of sustainability (environmental, economic, and social impacts). The key factors that are used to identify whether the concrete is green are (amount of Portland cement replacement materials, manufacturing process, and methods, performance and lifecycle sustainability impacts) (Imbabi,2012).

The waste generated from construction sites is considered one of the most irritating problems in Egypt. In the last 10 years, some effort has been made toward solving this problem, the most outstanding is the newly issued Egyptian rating system "Green Pyramids Rating System'. It emphasizes on waste management and particularly "site provision and environment' 'which contributes to $75 \%$ of the management category score. However, the traditional practice which is limited to dumping all the generated waste is still dominating (Abdelhamid,2014). but the physical properties of recycling aggregates differ from the natural one as (Pandaa,2012) observed that at age in 28 days test concrete marginally achieves required compressive strength up to 0.30 replacement ratio and recycled coarse aggregates show higher water absorption compared with conventional natural coarse aggregates due to old mortar attached with original concrete and has relatively lower specific gravity.

(Cakır,2014) showed that compressive strength of the recycled coarse aggregates concrete gradually decreases as the amount of recycled coarse aggregates increases. At full replacement level, the concrete strength decreases about $24 \%$ at 28 days.

(Martnmorales et al, 2013) found that mixture of recycled aggregates with moderate amounts of coarse aggregates is so it appropriate physical properties of concrete can be obtained in mixtures including coarse recycled aggregates.

(Siddiquea et al,2010) defined the foundry sand as waste material from foundries which exhibit lower unit weight, higher water absorption and a higher percentage of void compared to regular sand and he suggested that waste foundry sand can be used in making good concrete properties, and 
found that strength properties of concrete mixtures increase with the increase in foundry sand content. (Penkaitis et al, 2012) investigated that waste foundry sand is already used in building industry, paving and even as an agricultural compound and The mixtures of metals and organic compounds associated with the preparation of molds in each foundry process should be analyzed separately, in order to find viable alternatives for minimizing risks of environmental impact.

but (Marchioni et al, 2012) investigated that foundry sand on paving units and he prepared four samples with different mix design and different ranges of spent foundry sands were tested, so found that sample containing $15 \%$ of spent foundry sand presented itself in accordance with the Brazilian standards and thus could be normally used.

And (Aggarwa et al, 2014) agreed with him and showed that possibility of substituting natural fine aggregate with industrial by-product aggregates such as waste foundry sand and bottom ash offers technical, economic and environmental advantages which are of great importance in the present context of sustainability in the construction sector.

(Torres,2017) suggested that general foundry waste can be used to partially replace virgin aggregates in concrete, which can save natural resources and increases the amount of foundry waste recycled annually.

Also the using of marble dust may affect the environmental impact as (Deepankar et al, 2016) agreed with him that Based on the experiment result it showed that replacement of sand by marble powder up to $15 \%$ increased the compressive strength but replacement of cement up to $15 \%$ content of marble powder decreased the compressive strength and Durability of the mix containing different percentages of waste marble powder slightly increases with reference to the control mix.

(Patel et al, 2013) investigated that compressive strength increase when replacement of stone waste percentage increases when compared to traditional concrete.But (Munir et al,2017) found that compressive strength showed an increase in strength for specimens with 10\% WMP at 28 and 56 days. However, higher content of waste marble showed a decrease in strength as compared to control specimens. the Therefore, based on the results $10 \%$ waste marble powder can be effectively used in replacement of cement.

(Amit et al, 2016) studied that carrying out on concrete when marble dust is introduced in concrete as a fine aggregate replacement; it has been observed that workability decreased suddenly. So it has been concluded that marble dust decreased slump value (Workability) when marble dust is introduced in it. Compressive strength of concrete is decreased initially up to $50 \%$ then decreased suddenly however (Arel,2016) investigated that 5-10\% replacing of cement of marble dust will improve the concrete properties thus will decrease $\mathrm{CO}_{2}$ emissions to cement production.

The aims of this study was to describe the characteristics and performance of green concrete for reusable solid wastes and cement materials wastes to minimize its environmental negative effect, and discuss how the green concrete would be able to achieve sustainable construction.

\section{Methodology}

The present study includes a study of the production new mix designs of green concrete which have been conducted may be used in construction manufacturing field to make concrete production more sustainable, mainly focusing on reducing the consumption of natural resources.

\section{Materials:}

\section{Cement}

The type of cement that has been used is ordinary Portland cement (OPC) with a nominal particle size of $<90 \mu \mathrm{m}$ and compile with standard EN 197-1, table (1) show the physical and chemical properties of cement.

Table (1): Chemical composition and physical properties of ordinary Portland cement.

\begin{tabular}{l|l|l|l|l|l|l|l|l|l}
\hline Oxide & $\mathrm{SiO}^{2}$ & $\mathrm{Al} 2 \mathrm{O} 3$ & $\mathrm{Fe} 2 \mathrm{O} 3$ & $\mathrm{CaO}$ & $\mathrm{MgO}$ & $\mathrm{SO} 3$ & L.O.I & $\mathrm{Cl}^{-}$ & LSF \\
\hline
\end{tabular}

\begin{tabular}{c|c|c|c|c|c|c|c|c|c}
$\begin{array}{c}\text { Weight } \\
\%\end{array}$ & 20.8 & 5.19 & 3.653 & 63.41 & 1.179 & 2.48 & 2.63 & 0.025 & 0.92 \\
\hline
\end{tabular}

\section{Foundry Sand}

The sand used in this study, as a fine aggregate, is foundry sand from different foundries in Egypt the most of them from Houmdia area as (table 2) the physical and chemical properties. 
Table (2): Physical and chemical properties of foundry sand

\begin{tabular}{c|c|c|c|c|c|c|c}
\hline \multirow{2}{*}{ Test } & $\begin{array}{c}\text { Bulk density } \\
\mathrm{t} / \mathrm{m} 3\end{array}$ & $\begin{array}{c}\text { Absorption \% } \\
\leq 2 \%\end{array}$ & $\begin{array}{c}\text { Fines } \\
\text { content } \% \\
\leq 2.5 \% \text { by } \\
\text { weight }\end{array}$ & $\begin{array}{c}\text { Abrasion } \\
\text { index } \% \\
\leq 30 \%\end{array}$ & $\begin{array}{c}\text { Impact value \% } \\
\leq 45 \% \text { by weight }\end{array}$ & $\begin{array}{c}\text { Chloride \% } \\
\leq 0.04\end{array}$ & $\begin{array}{c}\text { Sulphates } \% \\
\leq 0.6\end{array}$ \\
\hline Results & 1.2 & 3.1 & 0.7 & 40 & 28 & 0.017 & 0.02 \\
\hline
\end{tabular}

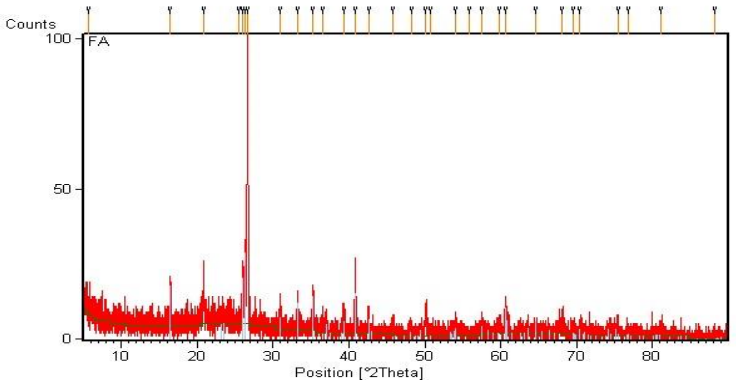

Figure (1): XRD-patterns of foundry sand peaks were at 28.689 $\AA$ which mean that Quartz was the only crystalline phase detected in the Foundry sand which contains $\mathrm{SiO}_{2}$.

\section{Demolition waste}

The construction waste used in this study was brought from many local areas in Egypt. This demolition waste has a grain size of 1- $4 \mathrm{~mm}$ after mechanical preparation of it, the physical and chemical properties as (table 3 ) as follows:

As (figure 1), The XRD results showed that main

Table (3) : Physical and chemical properties of Demolition waste

\begin{tabular}{c|c|c|c|c|c|c|c}
\hline \multirow{2}{*}{ Test } & \multicolumn{4}{|c|}{ Physical and mechanical properties } & \multicolumn{2}{c}{ Chemical composition } \\
\cline { 2 - 8 } & $\begin{array}{c}\text { Bulk } \\
\text { density } \\
\mathrm{t} / \mathrm{m} 3\end{array}$ & $\begin{array}{c}\text { Absorption \% } \\
\leq 2.5 \%\end{array}$ & $\begin{array}{c}\text { Fines } \\
\text { content \% } \\
\leq 3 \% \text { by } \\
\text { weight }\end{array}$ & $\begin{array}{c}\text { Abrasion } \\
\text { index \% } \\
\leq 30 \%\end{array}$ & $\begin{array}{c}\text { Impact value \% } \\
\leq 45 \% \text { by weight }\end{array}$ & $\begin{array}{c}\text { Chloride \% } \\
\leq 0.04\end{array}$ & $\begin{array}{c}\text { Sulphates } \\
\leq 0.4\end{array}$ \\
\hline Results & 1.2 & 5.5 & 0.8 & 40 & 28 & 0.017 & 0.01 \\
\hline
\end{tabular}

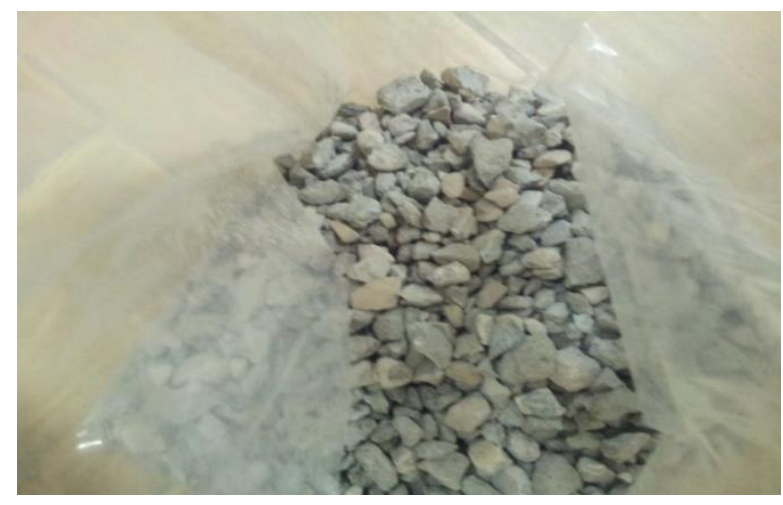

Figure (2): Demolition waste after mechanical preparation

\section{Marble Dust}

The marble dust (MB) waste used in this study was brought from a local manufacturer. This marble dust waste has a grain size of $0.15 \mu \mathrm{m}$, and bulk density of $0.15 \mathrm{~kg} / \mathrm{l}$. It contains extremely fine particles $(0.15 \mu \mathrm{m})$. as (table 4$)$ the physical and chemical properties of marble dust were showed.

Table (4): Chemical composition and physical properties of Marble Dust

\begin{tabular}{l|l|l|l|l|l|l|l|l}
\hline Oxide & $\mathrm{SiO} 2$ & $\mathrm{Al} 2 \mathrm{O} 3$ & $\mathrm{Fe} 2 \mathrm{O} 3$ & $\mathrm{CaO}$ & $\mathrm{MgO}$ & $\mathrm{SO} 3$ & L.O.I & $\begin{array}{l}\text { Free } \\
\mathrm{CaO}\end{array}$ \\
\hline $\begin{array}{l}\text { Weight } \\
\%\end{array}$ & 1.12 & 0.73 & 0.05 & 83.22 & 0.52 & 0.56 & 2.5 & 0.15 \\
\hline
\end{tabular}

XRD results in Figure 3 results clearly showed that marbles dust consists of mainly Calcite (CaCO3) and the small amount of Dolomite. The main peaks of Calcite were at 27.457 $35.919 \AA$ with the other minor peaks were determined.

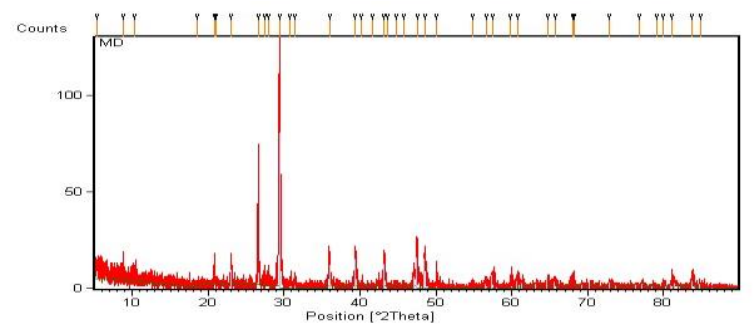

Figure (3): XRD-patterns of Marble Dust

\section{Method of investigation:}

The compressive strength of the hardened mortar pastes was determined at the different ages of hydration of 7, 28 and 90 days. The machine used in compressive strength measurements is model C089 concrete compression machine $2000 \mathrm{kn}$ high stability motorized, 1 gauge ,MATEST.

And then dried in a carbon dioxide-free oven at $105^{\circ} \mathrm{C}$ until it reached a constant weight. 
Scanning electron microscopy (SEM) was performed to study the morphology and microstructure of the hardened concrete trials; this was carried out on small pieces of the freshly fractured sample using a low voltage SEM, Inspect $S$ model. five mixtures were prepared in this study. which were used to prepare 75 standard cubes of size $(150 \times 150 \times 150) \mathrm{mm}$. For the compressive strength test, three cubes were tested at each age of hydration (7, 28 and 90 days) and the average value was recorded.

The mixing was performed using dry mixing for all materials followed by addition of mixing water after the dry mixing. The mixer used in this study is shown in the table(5)

Table (5): Mix proportions for all dry mixtures and their designations.

\begin{tabular}{c|c|c|c|c|c}
\hline Mix & $\begin{array}{c}\text { Cement } \\
(\mathrm{g})\end{array}$ & $\begin{array}{c}\text { Sand } \\
(\mathrm{g})\end{array}$ & $\begin{array}{c}\text { Aggregate } \\
(\mathrm{g})\end{array}$ & $\begin{array}{c}\text { Water } \\
(\mathrm{ml})\end{array}$ & $\begin{array}{c}\text { Marble } \\
\text { dust } \\
(\mathrm{g})\end{array}$ \\
\hline M0 & 3500 & 7500 & 11500 & 1900 & 0 \\
\hline M10 & 3150 & 7500 & 11500 & 1900 & 350 \\
\hline M20 & 2800 & 7500 & 11500 & 1900 & 700 \\
\hline M30 & 2450 & 7500 & 11500 & 1900 & 1050 \\
\hline M50 & 1750 & 7500 & 11500 & 1900 & 1750 \\
\hline
\end{tabular}

\section{Results and Discussion}

\section{Compressive Strength}

The compressive strength tests were conducted on the hardened concrete trials specimens after 7, 28 and 90 days of hydration. The compressive strength results of the hardened concrete trials made of the different concrete mixtures are listed in Table (5). The results were also compared to the hardened concrete specimens made of the OPC as control concrete with foundry sand and Demolition aggregates (M0) in order to illustrate the improvement extent in compressive strength as a result of marble dust. In addition, the results of compressive strength were analyzed to study the effect of age on strength development with different marble dust additions.

Table (5) clearly shows that all the concrete specimens made of OPC, with foundry sand and Demolition aggregates mixed with marble dust particles have more compressive strength than those the hardened concrete specimens with decreasing the cement content at all curing ages (7, 28 and 90 days). This leads to a conclusion that the addition of marble dust generally decreased the compressive strength of the hardened concrete specimens up to $50 \%$ marble dust addition.

The reason behind this strength decreasing is mainly the efficient packing of marble dust into the pore system of the concrete specimens mixes up to $50 \%$ marble dust addition; this leads to decreasing compressive strength values and more water was added which effect also in decreasing of the compressive strength.

The results of Table (6) showed that the concrete specimens mixture prepared with $50 \%$ of marble dust has attained the compressive strength which reached $76 \mathrm{~kg} / \mathrm{cm} 2$ after 28 days of hydration if compared with the cement content without marble dust. The decrease in strength values obtained for concrete specimens containing marble dust could be attributed to the fact that the addition of excessive marble dust that acted as filler in the hardened concrete specimens and thus decreased the strength in decreasing the cement content.

Table (6): Compressive strength results at the different ages of hydration

\begin{tabular}{c|c|c|c}
\hline \multirow{2}{*}{ Mixture I.D. } & \multicolumn{3}{|c}{ Compressive strength (kg/cm2) } \\
\cline { 2 - 4 } & 7 days & 28days & 90 days \\
\hline MO & 91 & 140 & 141 \\
\hline M10 & 65 & 92 & 91 \\
\hline M20 & 62 & 89 & 89 \\
\hline M30 & 55 & 84 & 83 \\
\hline M50 & 45 & 76 & 75 \\
\hline
\end{tabular}

\section{Scanning Electron Microscopy (SEM)}

The SEM micrograph obtained for the hardened concrete specimens made of mix M50is shown in Figures .(5-7) after 7, 28, and 90 days of hydration Figure (5) represents the SEM micrograph obtained for the hardened concrete specimens made of mix M50 after 7 days of hydration. Obviously, the microstructure is composed of nearly amorphous hydration products, mainly as calcium silicate hydration (CSH) and calcium hydroxide, around the cement and sand grains; pores with different size appeared also in the structure. The SEM micrograph obtained after 28 days of hydration is shown in Figure (6) which displayed the formation of the more dense structure of nearly amorphous and microcrystalline $\mathrm{CSH}$ hydrates with small hexagonal particles of calcium hydroxide (Figure 6). After 28 days of hydration, the microstructure of the hardened concrete specimens displayed the formation of small needles and short fiber of CSH hydrates which partially embedded; these hydrates are formed around in between the grains of hardened concrete specimens constituents with the appearance of some pores representing the residual pore system of the hardened concrete specimens of mix M50 (Figure 7). At the later age 
of hydration (90 days) denser microstructure is observed which composed mainly of excessive amount of microcrystal of CSH hydrates engulfed with $\mathrm{CH}$; these hydrates are accumulated and deposited in the pore system of the hardened concrete specimens leading to a marked decrease in both numbers and sizes of the residual pores (figure7).

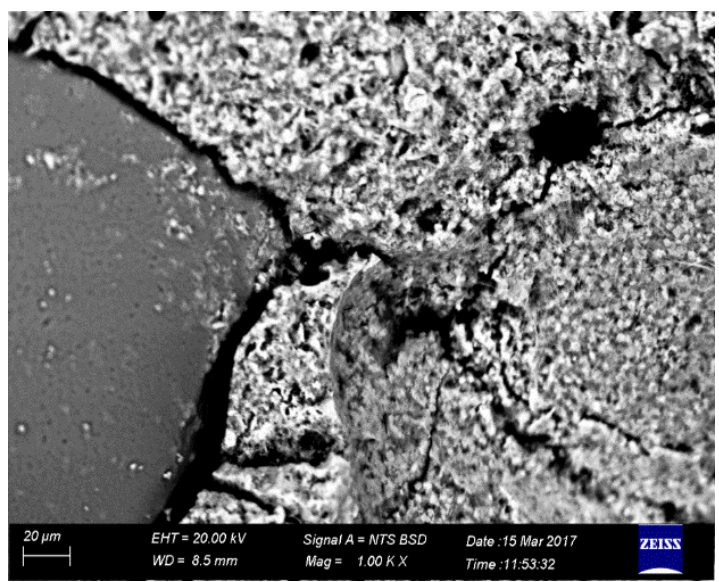

Figure (5): SEM micrograph of the hardened concrete specimens made of mix M50 after7 days of hydration

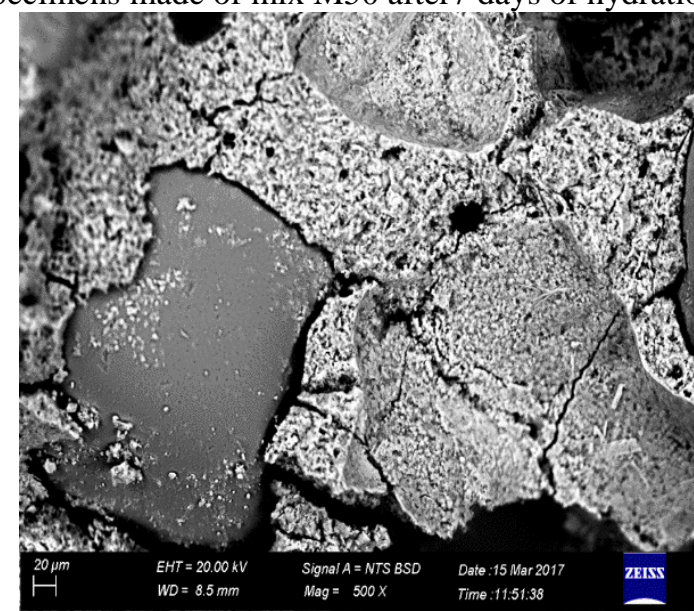

Figure(6): SEM micrograph of the hardened concrete specimens made of mix M50 after28 days of hydration.

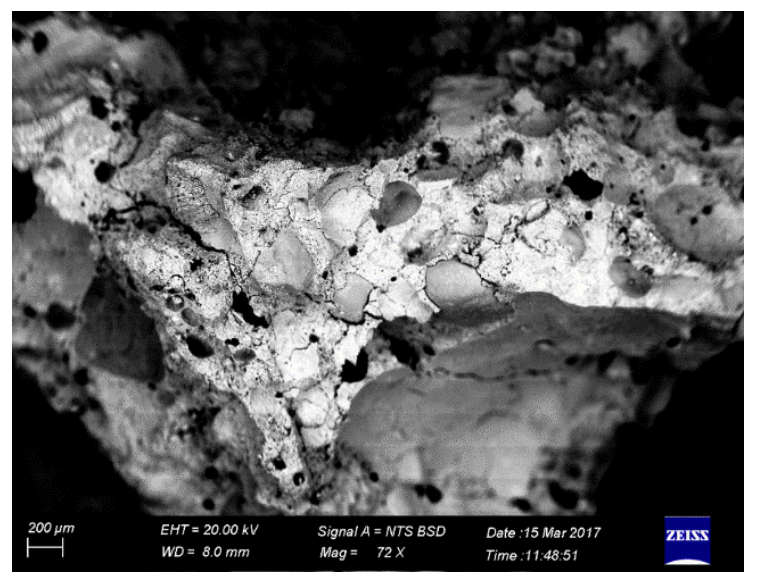

Figure (7): SEM micrograph of the hardened concrete specimens made of mix M50 after90 days of hydration

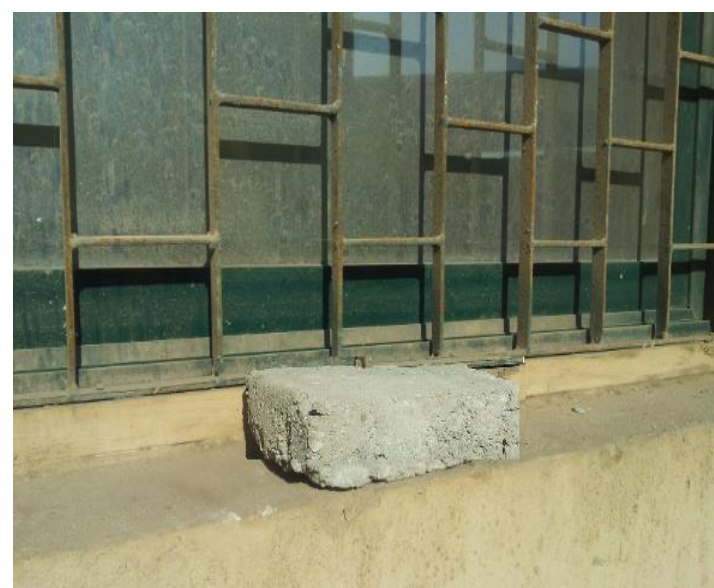

Figure (8): concrete brick sample by dimensions $25 \mathrm{x}$ $12 \times 6 \mathrm{~cm}$

\section{Conclusion}

(1) The utilization of wastes as marble powder, foundry sand and construction wastes in industrial brick production has been the objective of this study.

(2) The above wastes caused a great amount of environmental pollution so by reusing and recycling of these waste materials as raw materials in the manufacturing of industrial brick and other composite materials have a great contribution to the economy and to the environment by minimizing polluting effects coming from different plants.

(3) Based on the results of this study, the following conclusions can be drawn; In general, the addition of wastes played significant changes in the relevant functional characteristics like decreasing the compressive strength results so the mechanical properties of bricks were affected remarkably.

(4) Adding waste marble more than 10 wt.\% decreases the mechanical properties so increased the water absorption.

(5) The Egyptian Code shall be given a specification for the concrete bricks manufacturing so that the maximum tolerance for it shall be at least $70 \mathrm{~kg} / \mathrm{cm} 2$. This shall allow the replacement of the cement up to $50 \%$ by marble and in the same time using the foundry sand and construction wastes which giving the required compressive strength at a lower cost and higher using process for different types of these wastes. 


\section{References}

Abdelhamid Manal S. (2014) Assessment of different construction and demolition waste management approaches. HBRC Journal 10, 317-326

Aggarwal Yogeshand Rafat Siddique 2014 Microstructure and properties of concrete using bottom ash and waste foundry sand as partial replacement of fine aggregates ,Civil Engineering Department, Thapar University, Patiala 147004, India

Amit Nayak , P.H. Patil and A.C. Nayak,(2016), Utilization of Limestone Dust and Marble Dust in Concrete, IJSRD - International Journal for Scientific Research \& Development| Vol. 4, Issue 06, 2016 | ISSN (online): 2321-0613

Arel Hasan Şahan 2016. Recyclability of Waste Marble in Concrete Production,Faculty of Architecture, İzmir University, GürselAkselBulvarı, No:14, 35350, Üçkuyular / İzmir / Turkey

Cakır O. 2014. Experimental analysis of properties of recycled coarse aggregate (RCA) concrete with mineral additives, Y1ldiz Technical University, Department of Civil Engineering, 34220 Istanbul, Turkey

Deepankar Kumar Ashish, S K Verma, Ravi Kumar and Nitisha Sharma 2016. Properties of concrete incorporating waste marble powder as partial substitute of cement and sand, Maharaja Agrasen Institute of Technology, MAU, Baddi 174-103, India

Imbabi Mohammed S., Collette Carrigan, Sean McKenna (2012). Trends and developments in green cement and concrete technology. International Journal of Sustainable Built Environment (2012) 1, 194-216

Król M., Błaszczyński T. (2013). Geopolymer Ecoconcretes, Construction Materials, 11: 23-26.

Marchioni Jorge Lyra, Rafael Pileggi, Raquel Luisa Pereira ,Mariana L. and Claudio Oliveira 2012. Foundry Sand for Manufacturing Paving Units, Engineering. Associação Brasileira de Cimento Portland (ABCP) Av. Torres de Oliveira, 76 São Paulo, SP, BRASIL, CEP 05347-902.

Martín-morales m., m. Zamorano, i. Valverde-palacios, g. M. Cuenca-moyano and z. sánchezroldán,(2013), Quality control of recycled aggregates (RAs) from construction and demolition waste (CDW), University of Granada, Spain DOI: 10.1533/9780857096906.2.270

Moirangthem E., Meetei SL. (2017). A Review On
Green Concrete International Journal of Engineering Technology Science and Research IJETSR www.ijetsr.com; 4 (3): 2394 - 3386.

Munir Muhammad Junaid, Syed Minhaj Saleem Kazmi, Yu-Fei Wu ,(2017), Efficiency of waste marble powder in controlling alkali-silica reaction of concrete: A sustainable approach, Construction and Building Materials journal, 154 (2017) 590599.

PandaaK.C.and P K Balb 2012. Chemical, Properties of self compacting concrete using recycled coarse aggregate, Civil and Mechanical Engineering Tracks of 3rd Nirma University International Conference on Engineering (NUiCONE 2012)

Patel Ankit Nileshchandra and JayeshkumarPitroda 2013. Stone Waste :Effective Replacement Of Cement For Establishing Green Concrete, International Journal of Innovative Technology and Exploring Engineering (IJITEE) ISSN: 2278-3075, Volume-2, Issue-5

Penkaitis Gabriela and Joel BarbujianiSígolo 2012. Waste foundry sand. Environmental implicationandcharacterization, Resíduo de areia de fundição. Caracterização e implicação ambiental,DepartmentofSedimentaryand

Environmental Geology, InstituteofGeosciences, Universidade de São Paulo - USP, Rua do Lago 562, CEP: 05508-080, São Paulo

Safiuddin, M. Jumaat, M.Z. Salam, M. Islam, M. Hashim, R. (2010). Utilization of solid wastes in construction materials, International Journal of Physical Sciences. 5 (13): 1952-1963.

Siddiquea Rafat, Gurdeep Kaurb and Anita Rajorb,(2010), Waste foundry sand and its leachate characteristics,Department of Civil Engineering, Thapar University, Patiala (Punjab)-147004, India

Suhendro Bambang (2014). Toward green concrete for better sustainable environment, 2nd International Conference on Sustainable Civil Engineering Structures and Construction Materials 2014 (SCESCM 2014)

Tomas U. Ganiron Jr (2015). Recycling Concrete Debris from Construction and Demolition Waste. International Journal of Advanced Science and Technology.77:7-24. http://dx.doi.org/10.14257/ijast..77.02.

Torres Anthony , Laura Bartlett, Cole Pilgrim, (2017), Effect of foundry waste on the mechanical properties of Portland Cement Concrete , Construction and Building Materials journal 135 (2017) ,674-681. 


\section{عنوان البحث: مسحوق ركام البناء ورمل المسبك ومسحوق نفايات الرخام ؛ كمادة خام لإتتاج الطوب}

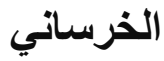

الجماهر عباس السكرى '، أمانى فريد عبده حسب اللهُ، أمنية عبد السلام البطراوى ‘، عبدالفتاح محمود غريب'، مي إبراهيم ' قسم الكيمياء غير عضوية، المركز القومي للبحوث البترول

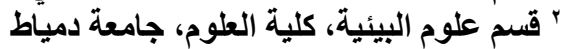

اهتم هذا البحث بلراسة استخدام مواد صديقة للبيئة في تصنيع مواد للبناء (الخرسانة) للحفاظ على البيئة وحماية الموارد

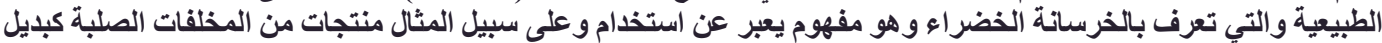

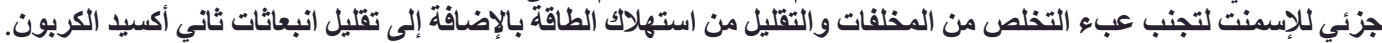

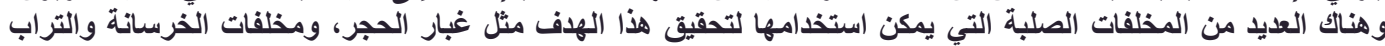
الرخامي وتراب مخلفات المسابلك.

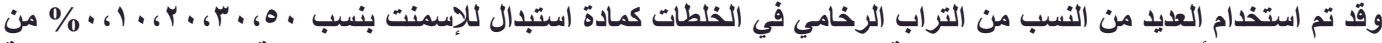

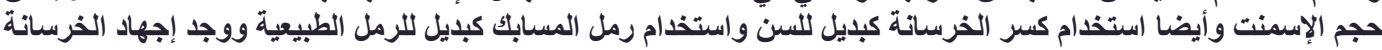

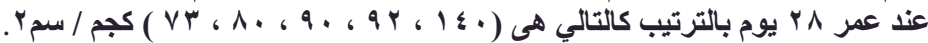

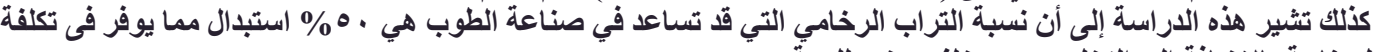

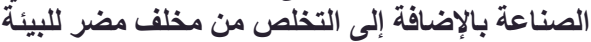

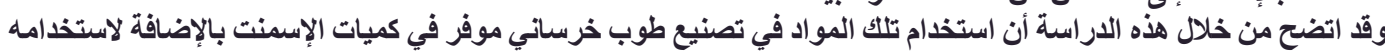
العديد من المواد التي تلوث البيئة وجعلها تساهم في انتهات التخاج منتجات صديقة للبيئة. 